\title{
Üllatustega silmkoeesemed
}

Riina Tomberg. Vatid, troid, vamsad. Silmkoelised kampsunid Eesti saartel. Tallinn: Eesti Kunstiakadeemia disainiteaduskonna rahvakultuuri õppetool 2004. Magistritöö. Juhendajad Annemor Sundbø ja Virve Tuubel. 54 lk, 2 lisa.

2004. aasta detsembris väitles end magistriks Riina Tomberg, kindla kunstnikukäekirjaga tegija. Ta andis oma väitekirjas esimese detailsema ülevaate kootud kampsunite ajaloost Eesti saartel ja neile kuni aastani 1930 osaks saanud kultuurilistest mõjutustest.

Esteetiliselt väga nauditavalt kujundatud ja samaaegselt informatiivse käsikirja juurde kuulub kataloog, kus silmkoetööd on järjestatud paikkondade järgi meeste- ning naistekampsuniteks. Kõigi juures on esitatud metaandmed (arhiivinumber, rahvapärane nimetus), eseme kirjeldus ja värvipilt. Läbi on töötatud Eesti muuseumide ja uurimiskeskuste (Eesti Rahva Muuseum, Eesti Rahvaluule Arhiiv, Eesti Keele Instituut) mahukad käsikirjalised kogud, kataloogitud on kuue kesk- ja kohaliku muuseumi (sh Läti, Soome) ning eramuuseumide eseme- ja fotokogud.

Ajaloolase Jacque Le Goffi sõnutsi vajab tänapäeval igasugune humaansus just ühiskonna ja kultuuri seotust ajalooga, sest see aitab meil orienteeruda olevikus ja tulevikus. Iga inimtegevuse nähtust tuleb seega uurides ja vaadeldes tema kasutamist ajaloolises kontekstis, milles ta omal ajal eksisteeris ja milles ta tänapäevalgi eksisteerib. Euroopa varrastel kudujate gildidele Eestis vastet ei leidu, kuid arvatavasti on üpris sarnane arengujoon, kus riideesemetele lood kudumist koopia, mis tihti võttis üle ka tekstiileseme varasema nime. Põhja-Euroopa kampsunite areng on kulgenud erinevaid teid pidi ja saanud erinevaid mõjutusi, näiteks on Inglismaalt ja Itaaliast levinud Skandinaaviasse siidkampsunid ja ka varane tööstuslik kudumine.

Paraku sisaldavad muuseumid arvukalt esemeid, mille tõlgendamine on olnud pikka aega üksnes fikseeriv või kirjeldav. Esemete asetamine laiemasse konteksti on olnud tagasihoidlik. Üheks põhjuseks on asjaolu, et rahvateadused on põhinenud kirjapandud tekstidel, mida on väärtustatud kõrgemalt kui asju, peetud nendest olulisemaks. Erinevalt on olnud väärtustatud ka tekstilisi ja muid visuaalseid esitamisviise. Sõnalooming säilib lisaks muuseumitekstidele näiteks raamatute ja kirjadena. Esemete säilitamispaigaks on tihti üksnes muuseumid, kus need paiknevad lahutatuna oma algsest ruumi- ja ajakontekstist. Osa neist on võimalik näha väljapanekutel, kus need esinevad kui mineviku majanduse, poliitika ja kultuuri “elavad" tunnistajad. Suuremat osa ei eksponeerita muuseumi näitustel kunagi, nende säilimine kodumiljöös on vähetõenäoline. Silmkoeesemed on just säärased, mille aeg ja koid - kui mitte kulumine - jäägitult hävitavad. 
Riina Tomberg kirjeldab ja rekonstrueerib seesuguste "elavate" tunnistajate elukäigu, nende sotsiaalse tähenduse (kampsunid kui eesti kihlakingid ja pulmarõivas, kui oluline pühaderõivas Hollandis), osutab pühadekudumite ja argikudumite erinevale värvusele, lihtrahva seas levinud kombele mugandada ja kopeerida kõrgklassi riietust.

Eesti saarte varrastel kootud kampsunite arengulugu 1860. aastatest kuni lokaalsete erijoonte kujunemiseni 19. sajandi lõpuks on mõjutusterohke ja kantud lokaalse identiteedi loomise vajadusestki. Nimetused, kudumistehnikad, kasutatud värvid, mustrid (väidetavalt on tugevaks mõjutajaks olnud ka trükitud mustrilehed), kudumitega seotud sotsiaalsed suhted, usuliikumiste mõjud (tagasihoidlik ühevärvilisus) moodustavad keeruka mustri.

Väitekirja juurde kuuluv praktiline töö on rajatud selle poisi kui piiride ületaja, ühest maailmast teise suunduja kujundile. Vahva on uudse tehnika (trükitehnika kudumil) sissetoomine, sest tõsi ta on, et rahvakunst on ajuti üpris suurte innovatsioonide vastuvõtja ja integreerija. Teise ettevalmistatud kollektsiooni põhikujund maailmapuu/maailmasammas koos lihtsate maagiliste märkidega on minimalistlik, mõjub nagu skitseeritud šamanistlik joonis - ilmikule mõistetamatu, kuid põnevile kehutav.

Iga katse ratsionaliseerida ajalugu, osutada, kuidas see kujunes, ületada sündmuste ja olukordade fragmenteeritus on teretulnud. Käesolevaga on alustatud suurte silmkoekudumite ajaloo, nendega seotud sotsiaalsete ja kultuuriliste sidemete, laenu- ja unikaalsusesuhete taastamist.

Mare Kõiva

\section{Magistritöö Lääne-Eesti pulmavaipade taasloomise võimalikkusest}

Christi Kütt. Lääne-Eesti pulmavaibad-etnograafiline aines, pedagoogiline ja loominguline aspekt. Magistritöö. Tallinn: Eesti Kunstiakadeemia 2005. Juhendajad Anu Raud ja Ene Kõresaar.

2002. aastal Eesti Kunstiakadeemia (EKA) disainiteaduskonnas avatud kunsti ja kultuuriantropoloogia magistriõppekava raames on kaitstud väitekirjade seas hakkab Christi Küti cum laude hinnatud töö silma etnograafilise ainese kasutamisvõimaluste tutvustamise seisukohalt. See pole pelk sedastamine, et Lääne-Eesti pulmavaibad on oma eripäraga pakuvad loomeainet ja õpetavad tehnikat, vaid traditsiooni jäljendamise ja taaselustamise katse.

www.folklore.ee/tagused 


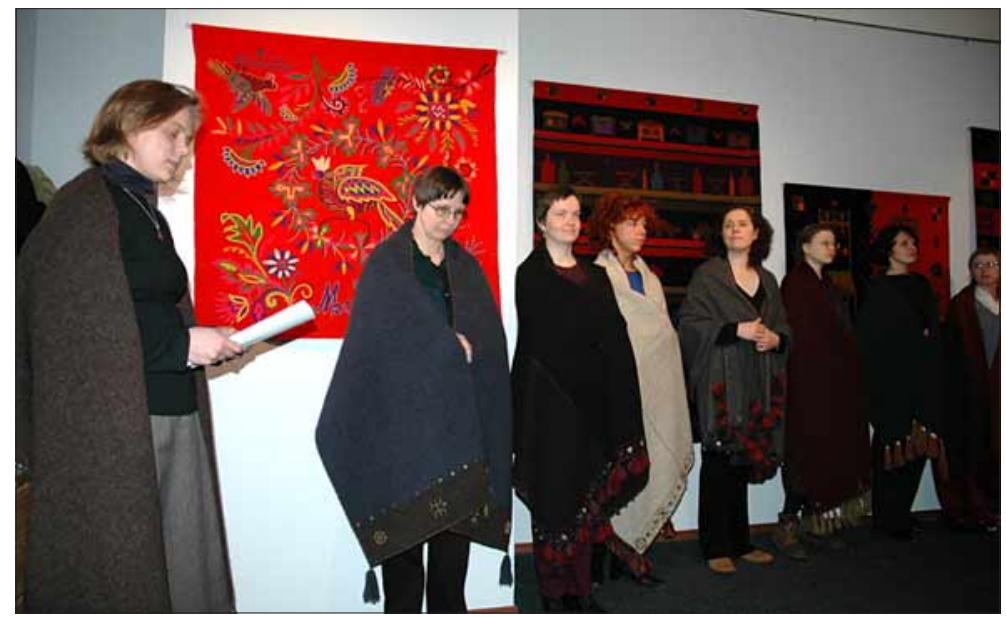

Foto 1. Christi Küti magistritöö kunstilise ehk praktilise osa moodustasid tema loodud Lääne-Eesti eeskujudele toetuvad pulmavaibad ja sõbad.

Magistritöö esimene, kirjalik osa, annab ülevaate kasutatud kirjalikust ja esemelisest materjalist. See ei ole akadeemiline uurimus. Christi Kütt on kasutanud arvatavalt kogu esemelist materjali, mida on võimalik meie muuseumides ja erakollektsioonides leida ning nii käsikirjalisi kui ka trükitud allikaid. Alapeatükis "Läänemaa kui kultuuripiirkond" on autor andnud igati vajaliku ülevaate selle ala ajaloolisest arengust. Kahjuks ei ole autor aga seletanud, mis põhjustel ta oma töös jätab välja Läänemaal paikneva Noarootsi kihelkonna vaibad. Viimane oleks oma ajalooliselt rootsilise asustusega ilmselt huvitav ja pakuks analüüsivõimalusi skandinaavia mõjude või nende puudumise kohta.

Peatükk "Läänemaa vaipadest muuseumides ja erakogudes" on käsitletav koos lisadega. Autor on kasutanud uurimustöös kõigi muuseumide kogusid, kus antud piirkonna vaipu võib leiduda. See on olnud pikk ja väga põhjalik töö. Vaibad on süstematiseeritud tehnikate järgi. Sellisest tööst on kindlasti abi olnud ka nendele muuseumidele, kus autor töötas. Autori töö on olnud selles vallas suurem kui magistritöö pealkiri seda võimaldab. Nimelt on ta töös korduvalt maininud, et käsitleb vaid Läänemaa mandriosa vaipu. Kasutatud muuseumikogude hulgas on aga ka Muhu muuseum ja Heimtali koduloomuuseum. Neist esimeses on valdavalt ju just Muhu saare tekid ja Heimtali osas on konkreetne viide Läänemaale vaid üheksa teki puhul (kuigi neid võib ilmselt rohkem olla) 57st. Vabaõhumuuseumi nimekirja juures sain ma aru nii, et eelkõige on käsitletud just eeldatavalt 
pulmavaipu, aga mitte ainult Läänemaalt. Läänemaal asuvate muuseumide kogudes on ilmselt valdav kohalik aines.

Peatükis "Lääne-Eesti vaibad 19. sajandi II poolest kuni 20. sajandi I pooleni” - mida allakirjutanud peab magistritöö kirjaliku osa põhiliseks ja kõige väärtuslikumaks - on vaibad süstematiseeritud tehnikate järgi. Autor on ka ise julgelt oma mõtteid väljendanud ja on tunda, et tegemist on materjaliga, mida ta läbi ja lõhki tunneb ning tänu sellele ka asjatundlikult analüüsib. Viidatud ei ole selles peatükis niivõrd kirjandusele kui just esemelisele materjalile ja see annab osale kaaluka teadusliku väärtuse.

Peatükis kombestikust ja kujundkeelest on kombestikku vaadeldud üldisemalt, pulmavaipade kujundikeele käsitlus aga lahendatud erakordselt intrigeerivalt. Figuraalsetele ehk jutustavatele kujunditele vaipadel on lisatud illustreerivaid tekste rahvapärimusest. Mõte on tore, valik väga hea ja tulemus suurepärane.

Eelnevast kasvab välja töö pedagoogiline aspekt, mis omakorda hargneb kahes täiesti erinevas suunas. Esiteks magistrandi isiklikule kogemusele toetuvad koopiavaipade kudumise õpetused ja teiseks põhikooli algastmele mõeldud värviraamat Lääne-Eesti pulmavaipade kujundikeelest.

Eelkõige avaldab muljet õpilastele mõeldud värviraamat. Tegemist on viimase osaga kirjatööst, mis on vormistatud kaunilt köidetud raamatuks. Tulevikus oleks kindlasti soovitav see trükis avaldada, sest just kunsti- ja käsitööõpetajatele oleks selline abimaterjal väga teretulnud.

Koopiavaipade kudumise õpetus on igati korrektne. Tundub, et isegi viited kudumistehnikate spetsialistile Mare Kelpmanile on üleliigsed, sest autor tundub ise sama hästi või paremini, kuidas kõnealuseid kirju tehniliselt kududa. Kiituseks on ka juba selle õpetuse järgi kootud vaibad.

Kolmas osa, autorikollektsioon kümnest sõbast ja seitsmest pulmavaibast, on EKA tava kohaselt kunstnikust kraadiõppuri magistritöö põhiosa. Looming on see, mis näitab, kes autor on, siin peegelduvad mitte ainult kunstniku mõttelend ja tehnilised oskused, vaid ka kõik tema akadeemilised teadmised.

Vaibad ja sõbad räägivad iseenda eest. Selleks, et kududa selliseid vaipu, peab inimene olema aine sees, tunnetama nähtamatut sidet enda ja kunagiste loojate vahel. Seda rütmi ja värvirõõmu ei saa vaiba sisse niisama lihtsalt, siin mängivad mingid kirjutamata seadused, mida saab tunda alles siis, kui sa oled läbi vaadanud ja käega katsunud sadu ammu enne sind kootud vaipu. Ja ainult selle kaudu tuleb just see õige tunne, mida tajume Christi Küti vaipu vaadates.

Piret Õunapuu 


\section{Halles Max Plancki Instituudis peeti 2004. aasta novembris rahvusvaheline juriidilise antropoloogia konverents}

Saksamaal Halles Max Plancki Sotsiaalantropoloogia Instituudis (MPI) peeti 26.-27. novembril 2004 juriidilise antropoloogia konverents Kord ja korratus (Order and Disorder).

Juriidiline antropoloogia (legal anthropology) on antropoloogia haru, mis on nn peavoolust suhteliselt kõrvale jäänud. Ehkki paari viimase aasta jooksul räägitakse sellest palju, ulatub juriidiline antropoloogia tegelikult tagasi 1950. aastatesse. Seekordne konverents, mille korraldasid MPI juriidilise antropoloogia osakonna teadurid Fernanda Pirie, Keebet von Benda-Beckman ja Franz von Benda-Beckman, oli keskendunud mõistete 'kord' ja 'korratus' (order and disorder) analüüsimisele nii teoreetilises perspektiivis kui ka erinevate situatsioonikäsitluste näitel. Viimane osa oli juriidilise antropoloogia seisukohast novaatorlik, sest ettekandjateks olid ka juriidilisest antropoloogiast kaugel olevad uurijad, kes üritasid oma materjali panna juriidilise antropoloogia teoreetilistesse raamidesse.

Teoreetilise osa juhatasid sisse distsipliini rajajad Simon Roberts, Peter Just, Johnatan Spencer ning Keebet ja Franz von Benda-Beckman. Nad juurdlesid oma ettekannetes korra mõiste suhtelisuse üle erinevates taustsüsteemides, nagu korra mõiste teaduslikus analüüsis (S. Roberts), kuid ka seaduse ja rituaalide (P. Just) ning poliitika (J. Spencer) seotus korraga. Empiirilist materjali pakkusid Aimar Ventsel (Siber), Bertram Turner (Maroko), Tilo Grätz (Lääne-Aafrika) ja Fernanda Pirie (Tiibet), demonstreerides just seda, et pole olemas ühtset, nn inimlikku arusaama kuriteost, vägivallast, aust ja uhkusest.

Geograafiliselt lai uurimispõld oli tervitatav kahel põhjusel: see annab parema pinnase võrdluseks ja diskussiooniks ning laiendab ka distsipliini ennast. Nimelt on senised juriidilise antropoloogia uurimused koondunud valdavalt Põhja-Aafrika ja Lõuna-Aasia rahvaste kogemuse vaatlustele.

Minule oli konverents huvitav kogemus ja uute ideede allikas, kuidas siduda oma sotsiaalantropoloogilisse uurimusse enam juriidilise antropoloogia diskursust.

Konverentsi materjalidest on ilmumas kogumik.

Aimar Ventsel 


\section{Ajaloolised looduslikud pühapaigad eile, täna ja homme}

Käesoleva aasta 17. märtsil peeti Tallinnas Eesti Rahvusraamatukogus esimene interdistsiplinaarne hiisi käsitlev teaduskonverents Ajaloolised looduslikud pühapaigad eile, täna, homme, korraldajateks Maavalla Koda, Muinsuskaitseamet, Eesti Kirjandusmuuseum, Eesti Rahvaluule Arhiiv ja Tartu Ülikooli ajaloo-osakond. ${ }^{1}$

Omausu märkidest tunnistust andvad pühapaigad looduses - mäed, hiie(metsa)d, puud, kivid, allikad, kalmed ja kabeliasemed - on oluline osa pärandkultuurist. Arheoloog Heiki Valgu sõnutsi erinevad eestlased teistest Euroopa põlisrahvastest selle poolest, et katoliiklikul keskajal, kui ristiusk oli üsnagi üleüldine, austas selle maanurga rahvas ikka veel põliseid looduslikke pühakohti ja kalmeid ning võttis uusigi kasutusele. Hiiumaal tulnud väidetavasti sellist käitumist ette ka pärast reformatsiooni.

Kuigi tänapäeval leidub Eesti maastikul arvukalt selliseidki kaitsealuseid omausuga seotud pühakohti või loodusobjekte, mis peegeldavad eestlaste minevikku suunatud passiivset kultuurimälu, on piisavalt neidki looduslikke kultusobjekte, mis on jätkuvalt seotud ühe või teise sotsiaalse rühma pärimuse ja kombekäitumisega ning nende objektidega on pärimuskandjatel kestvalt aktiivne side ja suhe - olgu nendeks pühad hiied Põhja-ja Lääne-Eestis, ristipuud Lõuna-Eestis, pühad kivid (Annekivi Setumaal) või allikad jms, kus käiakse tervist toomas või ennustatakse ilma.

On selge, et maastik kui ka suhtumine maastikuobjektidesse meie ümber on aastasadade jooksul muutunud - põhjuseks nii loomulikud looduslikud protsessid kui ka inimeste enda rohkem või vähem aktiivne majandustegevus ja muutused maailmavaates. Paraku on eestlaste ajalugu seotud võõrvallutustega. Aastasadu on siin enesekindlalt toimetanud suuremad rahvad ja nende valitsused, nii et julgesti võib küsida: kellele siis tegelikult kuuluvad maarahva pühapaigad metsas ja pühad kivid põllul? Kes otsustab tegelikult, milline mägi näiteks teetammi muldkehaks välja vedada, millised puud maha võtta, millised kivid või kabeliasemed ehitusmaterjaliks lõhkuda, et üksiti ka rahva ajaloolist/ religioosset mälu teadlikult või alateadlikult hävitada?

Nüüdisühiskonnas on pärandkultuuri kaitsmine väga keeruline - osa muinsuskaitsealuseid objekte on küll osa pärandkultuurist, aga suur osa pärandkultuuri objekte pole arvatud - ja karta on, et absoluutselt kõiki ei saagi arvata - kaitsealusteks. Muinsuskaitse ameti peadirektor Agne Trummal rõhutaski ses kontekstis, et tähtis on paiklik elav traditsioon, põlised kombed ja nende austamine kohaliku rahva seas ehk siis teisisõnu - kodanikualgatus. 
Rahvusvaheliste konventsioonide (bioloogilise mitmekesisuse konventsioon, ülemaailmne kultuuri- ja looduspäranadi kaitse konventsioon jne) kohaselt on Eestil kohustus oma loodus- ja kultuuripärandit ning põliskultuurist tulenevaid väärtusi kaitsta, rõhutas ka keskkonnajurist Kärt Vaarmari, kuid märkis sedagi, et pühapaikade kaitse alla võtmine kulgeb Eestis siiski valulikult - kohalikud omavalitsused kipuvad majanduspiiranguid kas põlgama või pelgama. Probleemiks - eriti traditsioonikandjate vaatekohast - on ka pühakohtade mentaalne ruum: võime võtta küll ühe või teise puu kivi ehk allika kaitse alla, tema olemasolu ja väärtuse sildiga kinnistada, kuid kui seal puudub inimesel võimalus näiteks volilt tulla-minna, järgida kombeid või sooritada rituaale, sest kaitsealune objekt asub näiteks eramaal, ei teeni selline kaitsmine sageli sisulist eesmärki.

Pühakohtade süsteemset kaitse alla võtmist takistab ka nende puudulik andmebaas - kahjuks pole teada, kui palju on loodusobjekte või pühapaiku, mis vältimatult vajaksid seaduse kaitset. Maavalla Koja vanema Ahto Kaasiku sõnutsi tuleks praeguste teadmiste kohaselt kaardil markeerida umbes 150 hiiemetsa ja 2500 muud looduslikku pühakohta või -objekti. A. Kaasik ja mitmed sõnavõtjadki rõhutasid iseäranis veel üht aspekti - lastele ei õpetata koolis, kuidas looduses, põlistes pühapaikades ja kalmistutel tuleb käituda. Näib, et värvilised sildid ja seletused on üksnes meelitamaks ligi turiste, kes ei tunne kohalikku keelt, kombeid ega kultuuri.

Kokkuvõtteks võib tõdeda, et riikliku hiite kaitse programmi käimalükkamiseks korraldatud konverents, mille avasõnad lausus kultuuriminister Urmas Paet, läks täie ette: kokku said oma ala asjatundjad kõrgkoolidest (Heiki Valk, Marju Kõivupuu, Jüri Metssalu), uurimisautustest (Mall Hiiemäe, Mari-Ann Remmel), riigiametitest (A. Trummal, K. Vaarmari, Aare Kasemets) ja omausuliikumisest (A. Kaasik). Arvukat publikut ja aktiivseid sõnavõitjaid jagus mõttetiheda päeva lõpuni.

Konverentsi materjalid ja märkmepaber olid trükitud Räpina paberivabrikus makulatuurist toodetud paberile. Allesjäänud vähesed puhtad lehed jagasin tuttavate lasteaialaste ja nende emade vahel - kõik tahtsid ehtsast, käe all sõbralik-soojana tunduvast paberist osa saada. Siinkohal teen üleskutse: kas mitte pärimuskultuuri uurimisega tegelevad institutsioonid ei peaks olema need, kes meie vohavas kriitvalges paberimajanduses senisest hoopis enam peaksid astuma loodussäästlikul rajal?

\section{Marju Torp-Kõivupuu}

\section{Kommentaar}

1 Teave konverentsist, teesid jms internetis (www.maavald.ee/ konverents.html). 


\section{Ersa keele päeva seminar Tartus}

Üllataval kombel pole ersa keele päeva tähistamine uuem kui meie eestlaste emakeelepäev, nii erinev kui ersalaste ja eestlaste emakeele seisund tänapäeva maailmas ongi. Ersa keele päeva tähistatakse 16. aprillil ja valiku aluseks on olnud Anatoli Rjabovi (1894-1938), ersa keelekorraldaja sünniaastapäev - eks seegi ole üsna analoogiline eestlastega, kelle emakeelepäevaks on saanud samuti sünnipäev - Kristjan Jaak Petersoni oma, kes polnud küll eesti keele uurija ega korraldaja, küll aga selle esimene luulekeeles ülistaja.

Eks keel ja luule, eriti rahvaluule, kuulugi kokku ja sellepärast pole viimased puudunud ka ersa keele päeva tähistamise kavast eelmistel aastatel ega ka tänavu. Nimetagem, et selle tähistamise taga on olnud peale kutsutud-seatud Fenno-Ugria Asutuse ka Eesti Ersa-Mokša Sõprade Selts. Fenno-Ugria on hoolitsenud tavaliselt külaliste kutsumisega seotud asjaajamise eest ja olnud finantstoeks. Küllakutsutute seas on olnud rahvalaulikuid, luuletajaid, kultuuritegelasi.

Mõnel aastal on olnud rohkem külalisi ja arvukamalt üritusi. Tänavused piirdusid külla kutsutud rahvalaulurühma esinemistega mitmel pool, alates Obinitsast ja lõpetades Tallinnaga, Tartut mõistagi vahele jätmata. Ersa rahvalaulurühma esinemine oli kindlasti asjakohane. Võib-olla Toorama eesotsas kadunud Vladimir Romaškini karismaatilise - tema puhul on see sageli väärkasutatud sõna õigel kohal - isikuga õpetas nooremaid kultuurihuvilisi eestlasi mõistma jälle seda, mida ütles - taas kadunud - Udo Kolk rohkem kui 40 aastat tagasi: "Volga rahvastel on võimas muusika." See oli lause, mis pani mind kõrvu kikki ajama, kuulama plaate ja hiljem ka elavaid ansambleid. Mõne aja pärast võisin tõdeda, et mu õppejõul oli olnud õigus.

Kuigi Toorama on jäänud vaimse juhita, on Eestis inimesi, keda ersa asi jätkuvalt huvitab. Toimekamad neist on koondunud seltsi, mida eespool juba nimetatud, ja seekordne seminar oli nende korraldatud.

Seminar peeti 15. aprillil ja üsna loogiliselt Tartu Ülikooli uurali keelte õppetooli ruumes. Avaettekandes analüüsis Heno Sarv ersa ja mokša identiteediga inimeste arvulist vahekorda 2002. aasta rahvaloenduse andmete põhjal. Juba teemast johtuvalt polnud oodatagi kibedaid tõdemusi selle kohta, et ersade-mokšade arv ja emakeeleoskus on kahanenud, jutt käis ainult nendest, kes pole venestunud, vaid on säilitanud oma identiteedi. Heno Sarv vaatles piirkonniti ja Mordva Vabariigi piires ka rajooniti, kui palju oli protsentuaalselt ennast ersadeks, kui palju mokšadeks ja kui palju mordvalasteks identifitseerinud inimesi. Kuuldud ettekanne ajendas mõtlema sellest, millel õieti püsib kahe lähisugukeeli kõneleva rahva ersa või mokša identiteet. 
Konkreetselt keelte juurde läkski mokša rahvusest Tartu Ülikooli magistrand Tatjana Zirnask oma süstemaatilises ja näitlikus ettekandes. Ta tegi selgeks, mis on ersa ja mokša keeles ühist, mis erinevat, alustades foneetikast ja lõpetades sõnavara vaatlusega, ja taas tundus, et keelelised erinevused pole kuigi suured, nii et ilmselt omavad suuremat kaalu muud tegurid. Aga millised?

Mõningaid ersa muinasjutte, millel on huvitavaid paralleele läänemeresoome, kuid ka balti rahvaste, eriti leedulaste repertuaaris, vaatles Kristi Salve. Ta osutas, et mõnikord on tegemist eraldi käsitletavate tüüpidega, vahel aga laiemalt levinud tüübi piirkondliku redaktsiooniga, mille sees omakorda võib eristada alaredaktsioone. Huvitavad on paar juhtumit, kus ersa variant võib olla lähemal balti (leedu) versioonile, olemata sellega siiski identne.

Väga huvitavad olid kaks järgmist ettekannet, mis haakusid omavahel (ja mõnevõrra ka T. Zirnaski omaga). Niina Aasmäe, kelle uurimisteemaks on ersa keele - tema enda emakeele - prosoodia, küsis pealkirjas "Kas ersa keel on prosoodia poolest ühtne" ja vastas sellele eitavalt. Aluseks oli autori koostatud kavala küsitluskavaga kogutud teatud hulk kordi lausutud samu sõnu ühe või teise murde kõnelejatelt. Nende põhjal tehtud akustiliste mõõtmise tulemusena täheldati murdeti üpris olulisi erinevusi.

Taive Särje ettekanne oli tõeliselt põnev, nagu näitas sellele järgnenud elav mõttevahetuski. T. Särg oli teinud eksperimendi Tartu Ülikooli Õpetajate Seminari tudengitega, kellel ta laskis kuulata ersa laulu ja seejärel märkida ära need silpnoodid, mida tajuti rõhulistena. Tulemuseks oli, et muusikaliselt rõhulised, ersa keele loogika kohaselt rõhulised ja katsealuste poolt rõhulistena tajutud silbid moodustasid väga kirju ja ettearvamatu kombinatsioonidehulga.

Teemapäeva lõpus vaadati mullu Tallinna Pedagoogikaülikooli bakalaureusetööna valminud Mare Albri filmi Sõnumeid ersade maalt. Filmi kommenteeris Indrek Särg, kes oli ise selle valmimisel osalenud ja kellel oli ühtlasi varasem isiklik kogemus filmi keskmes olevast rahvuslikust pidustusest Rasken $O z k s$. Nii avanes võimalus ka võrdluseks. Ilmnes, et mõne aasta tagusega võrreldes oli pidustus muutunud institutsionaalsemaks ja kommertslikumaks, aga see on vist juba loodusseadus.

Huviliste mõttevahetus jätkus pärast ettekannete lõppu kohvilauas, kus rühmiti vestlejate jutust kostis umbes selliseid lausekatkeid: "[---] aga rõhutu silbi vokaal ometi [---]”, “[---] kui aluseks võtta Bojarkini noodistused [---]", "[---] sul on vist õigus nende paralleelide suhtes läänemeresoomlastega [---]”, “[---] kas sa arheoloogide seisukohti tead?” ning kordus ikka ja erinevais seostes "ersa" ja "mokša".

Kristi Salve 


\section{Torm, Kevadtorm ja folkloristikaseminar 24.-25. mail 2005}

Eesti kaitsevägi korraldab kevaditi suurõppusi Kevadtorm, Eesti Kirjandusmuuseumi folkloristikaosakonna töötajad arutlevad maikuuseminaridel päevakorral olevate uurimisteemade üle. Torm 24. mai õhtul Valgamaal kujunes looduslikuks kontekstiks nii sõjameestele Urvastes ja Sangastes kui ka seminaristidele Nõunis asuvas Mesilinnu Saloonis. Lõi välku ja müristas.

Tavapäraselt kuulub folkloristikaosakonna väljasõiduistungi juurde ringsõit või rännak ümbruskonnas. Teekonnal Sangaste lossi sattusime otse Kevadtormi keerisesse. Möödusime teeäärsetel põldudel ja metsatukkades varitsevatest kaitseväelastest. Vastassuunas liikus mitmesuguseid sõjamasinaid, mis sisendasid kindlusetunnet, et meid kaitstakse ja saame folkloristikaga rahulikult edasi tegelda.

Enne teisipäevaõhtust tormi ja vihma veetsime mitu päikeselist tundi oues ettekandeid kuulates ja kuluaarivestlusi pidades. Silm puhkas samal ajal Otepää kihelkonna maastikukumerustel ning tallu kokku kantud veskikividel, puunikerdustel ja muul vanavaral.

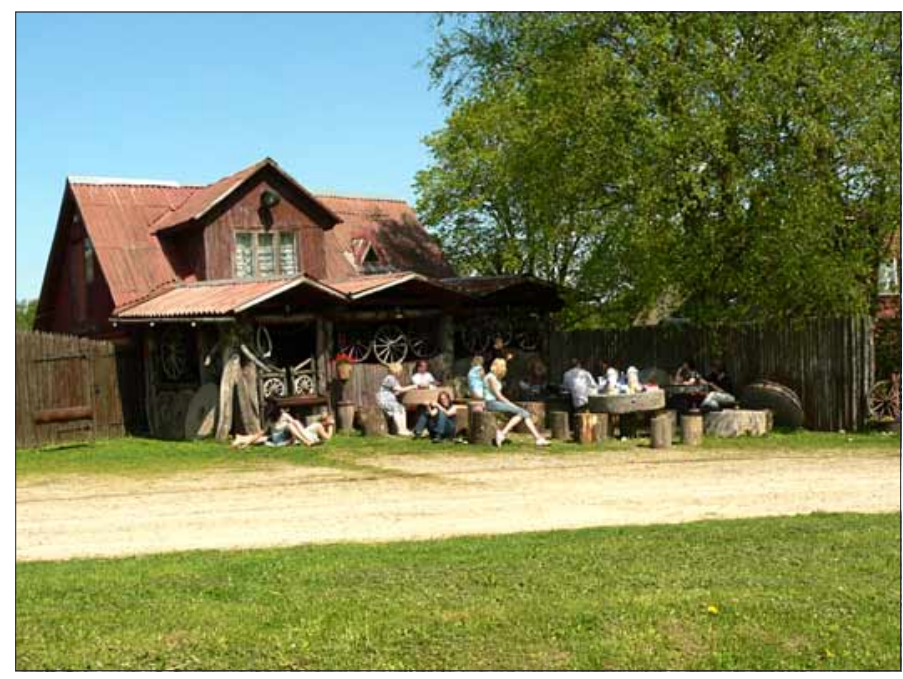

Foto 2. Ilus ilm lubas pidada seminari Mesilinnu Salooni õuel. Andres Kuperjanovi foto. 2005. 


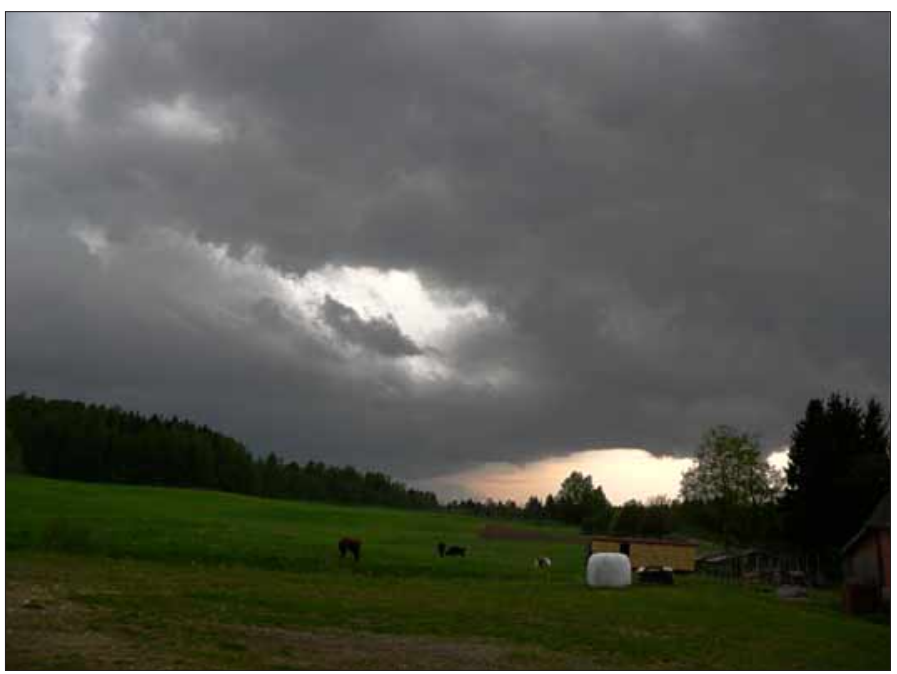

Foto 1. Seminari esimese päeva, 24. mai õhtuks taevasse kogunenud pilved tõid tormi, müristamist ja taevatuld.Andres Kuperjanovi foto. 2005.

Jõulise avalöögi andis seminarile Aimar Ventseli sõnavõtt "Kunst, popmuusika ja Sahha identiteet". Sotsiaalantropoloogi asjatundlikkusega iseloomustas kõneleja Jakuutias (omanimega Sahha Vabariigis) elavate inimeste suhteid, valikuid ja hakkamasaamist, kuid ka probleeme. Arutelul süveneti üldisematesse identiteeti kujundavatesse probleemidesse, näiteks teemale, mis loob meie-tunde, kes ja kuidas kujundab võõra-kategooriaid ja kuidas etnoloog (laias tähenduses) sulandub uuritavasse rühma.

Semiootik Renata Sõukand arutles platseeboefekti üle. "Ta toimib siiski," jõuti ühisele järeldusele. Nagu R. Sõukand näitas, on mõisteala raames palju huvitavaid detaile ja mõjusuundi, mida esile tuua ja lähemalt analüüsida. Siit suundub ka teerada mõningate rahvameditsiini kohta tehtud aksiomaatiliste järelduste teisitisõnastamise suunas.

Arvo Krikmann pidas ergutava loengu uuematest huumoriteooriatest. Sõltuvalt vaatluse suunast on eristatavad leevendus-, üleoleku- ja vasturääkivusteooriad, millest igaühele on ka hulka sünonüümseid mõisteid. Lähemalt õppisime tundma vasturääkivus- ehk bisotsiatiivseid ehk kognitiivseid meetodeid (Arthur Koestler, Viktor Raskin, Salvatore Attardo). Nagu A. Krikmann näitas, on kognitivistide kasutuses vahendid, millega saab näidata nalja toimemehhanisme: nali algab ühe ja lõpeb teise skeemi rüpes. Pärast loengut aktiveerusid nii mõnedki naljaskriptid.

Rein Saukas, üks folkloristikaosakonna kompetentsematest tekstoloogidest ja rahvaluule kui teaduse ajaloo tundjatest analüüsis Walter 
Andersoni omapärast ja meetodikindluses lausa pedantset lastelaulude kollektsiooni. A. Krikmann ja teised suurte andmehulkadega töötanud kogenud kolleegid vangutasid mõtlikult päid: kuidas kohelda selliseid omas stiilis täiuslikke tekstimassiive, mida tegelikku uurimistöösse lülitada on keeruline või tulemusetu.

Kui saabus õhtu ja algas sadu, jätkasime majakeses. Kui täpne olla, siis struktureeris vihm mitte ainult seminari, vaid Rein Sauka ettekande, millest pool jäi õue, pool jätkus ümarlauas. Nüüd suunasime oma pilgud helendavale arvutiekraanile, kus demonstreeriti tegelikkuse mitmesuguseid pildilisi ja verbaalseid representatsioone.

Sõna sai Anneli Baran, kelle ettekande pealkiri kõlas "Kiel on kõige kurjem liige ehk kõnelemisest kõnekäändudes". Nii see paistis ka olevat, sest puhkes konkreetsete näidete tõlgendusvõimalustest ja kontekstisidususest inspireeritud arutelu. Jutu-uurijast ülevaatekirjutaja kõrv tabas fraase, nagu fraseologism ja kõnekäänd, fraseologism kui kõne käänd (nimme lahku kirjutatud), fraseologism või kõnekäänd, lingvistika ja folkloristika jne. Igatahes on A. Baran oma uurimisteema raames teinud tõsist tööd kõnekäänu kui žanri teooriatega.

Allakirjutanu ettekanne pealkirjaga "Vanapagana baarikapi külalistest” käsitles geopeitust kui uut mängu, mille käigus peidetakse pärismaastikule mänguaardeid ja otsitakse neid, kusjuures peidikute geograa-

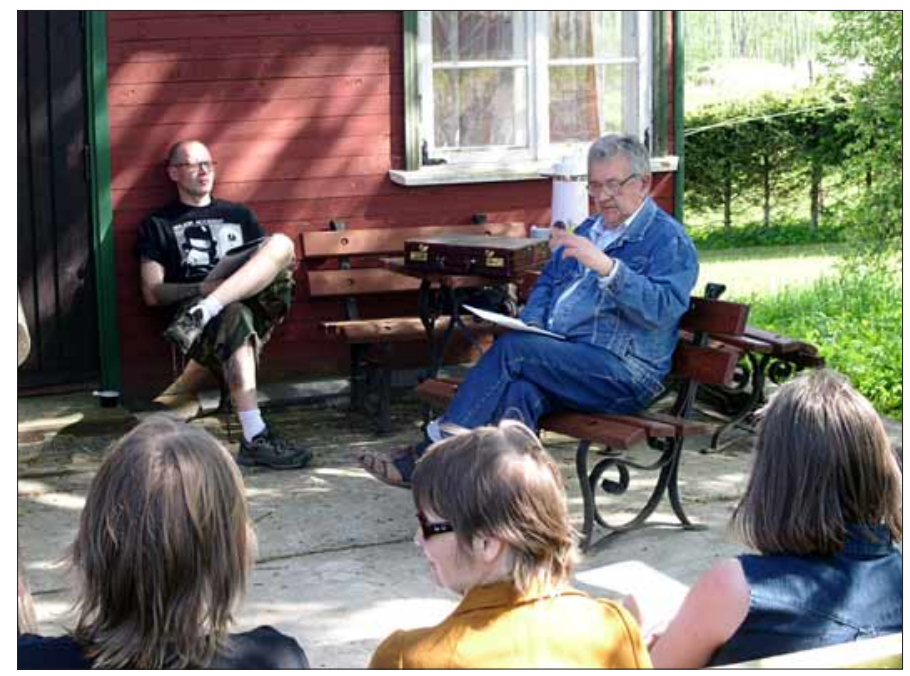

Foto 3. Ettekannet peab Arvo Krikmann (paremal), teda jälgib pingsalt Aimar Ventsel (vasakul). Andres Kuperjanovi foto. 2005. 


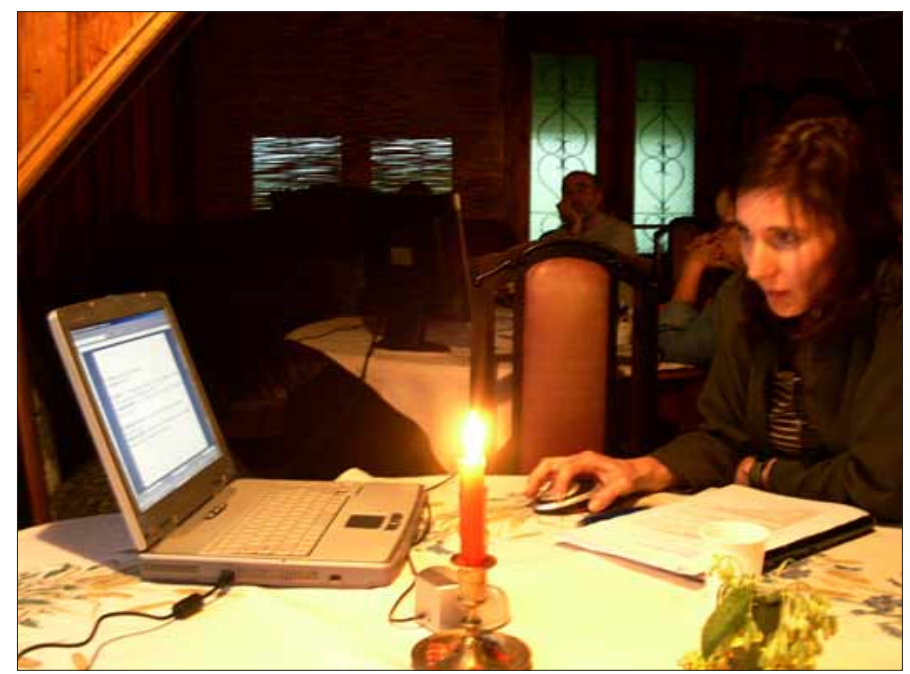

Foto 4. Kui torm seminaripidajad katuse alla peletas, keskendusid kuulajate pilgud ettekandeid ilmestavale arvutiekraanile. Sõnajärg on Anneli Baranil.Andres Kuperjanovi foto. 2005.

filised koordinaadid on määratud GPSi abil. Geopeituse kui harrastuse infovahetuses asetatakse muistendeid uutesse seostesse ja luuakse uusi isikukogemuse jutte. Palju auru läks valgustustegevusele seni geomugudest kolleegide (st asjassepühendamatute) hulgas.

Nikolai Kuznetsov oli osa võtnud kirevast kongressist IFUSCO 2005, kus tooni andsid avangardsed ideed ja ootamatud lähenemisnurgad soomeugri lingvistikas, kirjandusteoorias, folkloristikas ja etnoloogias ja millel ei puudunud ka oma festivalipool. Läbimõeldud tutvustuse kaudu said kuulajad objektiivset teavet noorsoomeugrilikust humanitaariast.

Kõigi maailma folkloristide hüvanguks töötab Karin Maria Rooleid, kes koostab folkloristikabibliograafia märksõnade loendeid. Ta andis ülevaate lõpututest mõistelistest raskustest, millega niisuguse töö tegijal tuleb paratamatult võidelda. Seminaristid väljendasid siirast imetlust tehtu üle ja pakkusid moraalset tuge edaspidiseks.

Kokkuvõtteks. Kevadtorm 2005 juht hindas õppusi kordaläinuks, sest saadi hulga uusi ideid, mida ellu viia. Ka folkloristikaosakonna samal ajal peetud seminar läks korda. Väljasõidust osavõtjate moraal oli väga kõrge ja pingetaluvus vastas igati oma maad ja rahvast uuriva teadlase tasemele.

Mare Kalda 


\section{Eesti Kunstiakadeemia 27. soome-ugri uurimisreis Setumaale}

2004. aasta juulikuus töötas Eesti Kunstiakadeemia (EKA) kümneliikmeline tudengirühm Setumaal - Eesti ja Vene Föderatsiooni aladel eesmärgiga leida ja jäädvustada rahvakunsti seisukohalt huvipakkuvat materjali etnograafiliste jooniste ja fotodena. Töötati nii riiklikes kui ka eramuuseumides (Radaja), kuid peamiselt põliste külaelanike juures. Välitöödelt toodi kaasa üle 250 etnograafilise joonistuse-mõõdistuse ja üle 2500 fotokaadri inimestest, igapäevaelust ja olmest, ümbruskonna loodusest, arhitektuurist ja esemetest, samuti vanade fotode skaneeringuid. Emotsionaalselt teravat võrdlust pakkus Setumaa, kui ajalooliselt ja kultuuriliselt ühtse piirkonna, kultuuriprotsesside jälgimine mõlemal pool

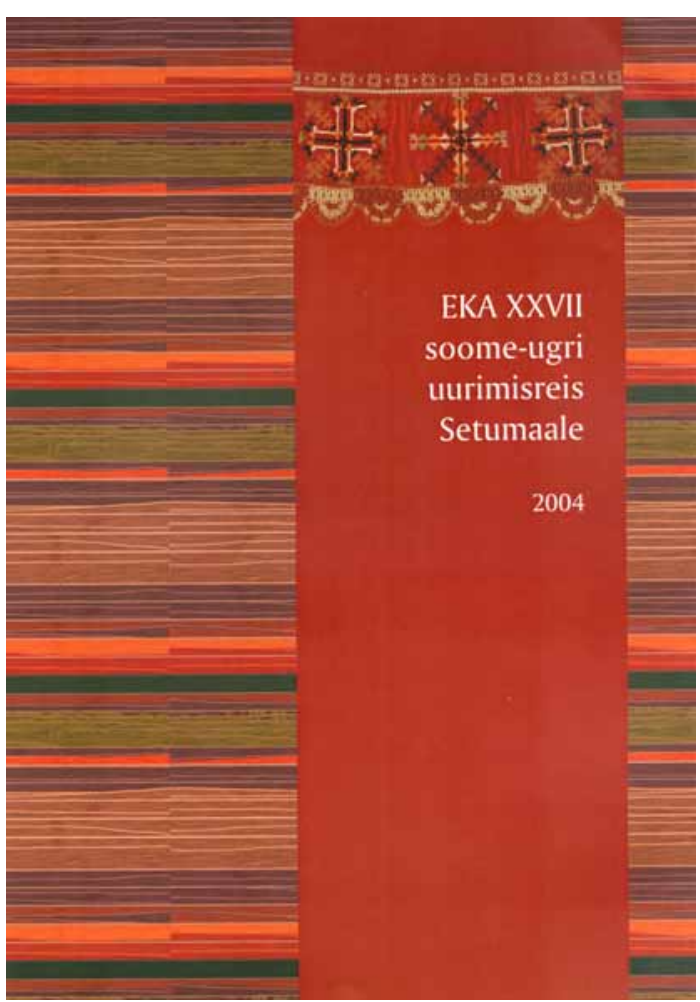

Foto 1. Setumaa välitööde kogumiku kaas.
Eesti ja Vene Föderatsiooni vahelist kontrolljoont.

Setumaale iseloomulikku eriti peent ja arenenud naiskäsitööd - traditsioonilisi rõivaesemeid, vöid, pühaserätte, linikuid - on paljudes peredes tänapäevani alal hoitud. Välitööde käigus küsitleti vanema põlve meistreid, kes teadsid pajatada esemete saamisloost, kirjadest, värvidest ja nendega seotud kommetest. Samavõrd pakkus huvi Setu aladele iseloomulik taluarhitektuur, elamusisustus ja kodukujundus.

Töötati Saatse Seto Muuseumis ja ümbruskonnas - Saabolda, Tsütski, Perdagu, Kundruse, Samarina jt küla- 
des. Pihkva oblastis peatuti pikemalt Irboskas, kus tutvuti Pihkva Ajaloo- ja Arheoloogiamuuseumi hallatava Setu talumuuseumiga Radaja (Sigova) külas. Samas paikneb ka setu rahvakunsti erakollektsioon, mille hoiutingimused ja saatus tekitavad muret. Petserimaale jäänud eakaid setu peresid külastati Kaatsova, Lõkova, Ugarova, Pankjavitsa, Poroslova, Keera, Sapja, Kossolka, Saltanuva, Metkavitsa, Pööni, Ungavitsa, Podlesja, Truba, Podkorja, Raakva, Trõnnõ, Sokolova jt külades.

Setumaa välitööde etnograafiliste joonistuste ja fotode näitust "Seto" täämbä" on eksponeeritud hõimupäevade ajal Akadeemilises Raamatukogus, Viljandi Linnagaleriis koos Viljandi Kultuuri-

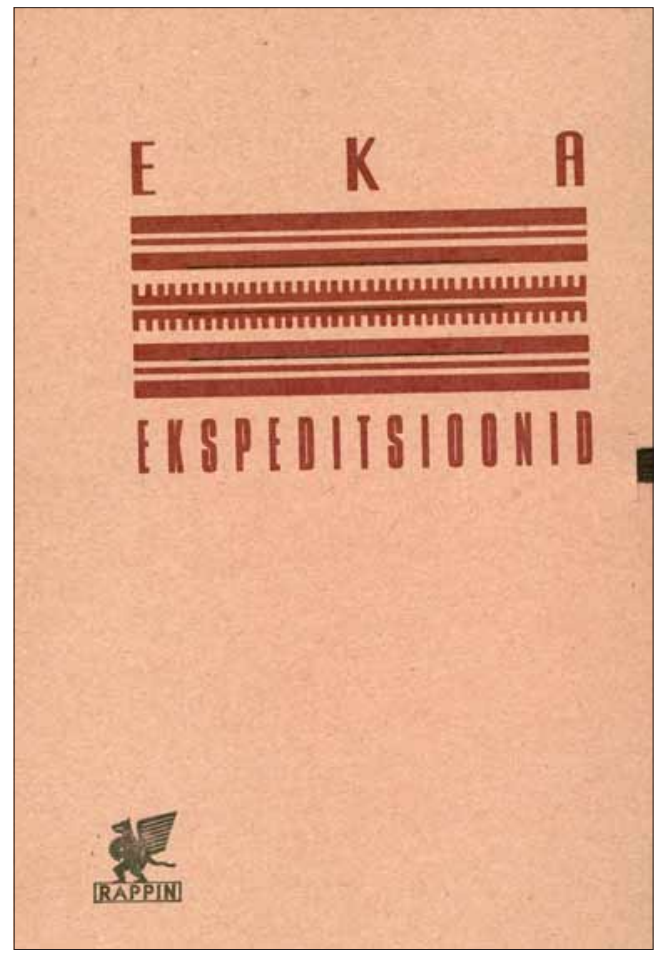

Foto 2. Eesti Kunstiakadeemia uurimisreiside logo. akadeemia rahvusliku käsitöö eriala vastavateemaliste töödega ja Eesti Kunstiakadeemia galeriis seoses ettekandepäevaga.

6. aprillil 2005 esinesid välitöödel osalenud üliõpilased temaatiliste lühiuurimustega Eesti Kunstiakadeemias korraldatud ettekandepäeval. Ettekannetes käsitleti traditsiooniliste setu rahvakunstialade, nagu rõivastus, sisustustekstiilid ja ehted, kõrval kodukujundust, ehituskunsti ja linakasvatust. Pikemalt peatuti Setumaaga seotud kunstnike loomingul ja nüüdisaegsel kunstialasel tegevusel. Eraldi käsitlemist leidis vanade fotodega seotud teema.

Ettekannete päeval esitles EKA soome-ugri uurimisreiside juht Kadri Viires Setumaa välitööde kogumikku, kuhu on koondatud valik välitöödel tehtud etnograafilisi joonistusi, vanade fotode skaneeringuid ja ettekannete tekstid.

Kadri Viires 


\section{Vana uudis metsikute kunstisügisest, kus üritati solvata meduusi, ja mõned uuemad pudemed pärimuskunsti valdkonnast}

Tallinna Kunstihoones KU eksponeeriti 10. oktoobrist 9. novembrini 2003 rahvusvahelist autsaiderite ja art brut'i (otsetõlkes: toores, töötlemata kunst, st mitteakadeemiline kunst) näitust ning 17. ja 18. oktoobril 2003 peeti samas rahvusvaheline konverents ja linastus filmiprogramm "Solvates meduusi".

KUs sai näha art brut'i klassikat Pariisis asuvast ABCD-kogust, st vaimuhaigete kunsti kogust (Aloïse, Carlo, Henry Darger, Magde Gill, Johann Hauser, Augustine Lesage, AdolfWölfli). Lisaks oli KUs ja Kullo galeriis väljas nn metsikute kunst Eestist ja ITE-kunst (ITE on soomekeelne termin nn külakunsti kohta: itse tehty elämä 'ise loodud elu') Soomest.

Konverentsil, mis keskendus loovuse ja hulluse temaatikale kunstis, tegi põhiettekande "Kahtlasest sümptomist suurepärase väljenduseni: Kunsti õitsemine psühhiaatriainstitutsioonides" (From Dubious Symptom to Admirable Expression: The Flowering of Art within the Psychiatric Institution) Suurbritannias Cantebury's asuva Kenti ülikooli Rutherfordi Kolledži draama, filmi ja visuaalsete kunstide kooli (School of Drama, Film \& Visual Arts Rutherford College University of Kent Canterbury) professor Roger Cardinal, kes lähtus mh Hans Prinzhornist, Walter Morgenthalerist, André Bretonist ja Jean Dubuffeti'ist.

Teised esinejad olid Euroopa Folkloori Instituudi direktor professor Mihály Hoppál, Sankt-Peterburgi psühhiaatriahaigla terapeut, kunstnik ja professor Andrei Gnezdilov, Soome ITE-näituste kuraator Erkki Pirtola, KU kuraator Anders Härm ja kunstiajaloolane Sigrid Saarep, Puuetega Inimeste Kunstiühingu kunstiõpetaja Anneli Säre, Viimsi haigla arst Natalja Zenevitš, kirjanik ja psühhiaater Vaino Vahing ning kunstiteaduste doktor Katrin Kivimaa Leedsi ülikoolist.

Filmiprogrammis näidati Liina Kullese linateaost Maailm nagu muster Harri Aerust (Eesti 1996, 30 min); Erkki Pirtola filme ITE-kunstnikud Soomes (Soome) ja Adelbert Juks (Soome 2002, 20 min); Veli Granö Matias Keskise pildiks muudetud elu (Soome 1991, 55 min); Alan Governar' ja Bob Tullier' filmi prantsuse kunstnikust Jaberist (Prantsuse-USA, 16 min); Bruno Decharme'i Aleksander Lobanovi elu ja loomingut käsitlevat linateost (Prantsusmaa, 7 min); Joseff Pacskovszky filmi kunstnik Mihaly Scheknerist (Ungari 2001, 29 min) ning Tamas Ocsenase Edit Kremsieri kujutust doktor Andras Petöst (Ungari 2001, $52 \mathrm{~min}$ ).

Üritustest ilmusid 7. novembril 2003 kultuurilehe Sirp eriküljed "Outsider". 
Eesti pärimuskunstnike galerii asub internetis aadressil http:// www.metsas.ee/et/galeriimetsikud.

Portaaliga metsas.ee liitus septembris 2004 nüüdisaegset pärimuskunsti ja art brut'i kajastav veebigalerii METSIKUD. Galerist on Sigrid Saarep. Galerii nimi annab vihje, et esitletavad kunstiviljad ei pärine kultiveeritud ja "akadeemilise" väetisega aiast, vaid on kasvanud metsikult looduse enda tahtest. Pilte toetavad teoreetilised tekstid.

Helsingi kaasaegse kunsti muuseumis Kiasmas avati 14. mail 2005 mitteakadeemilise ehk metsiku kunsti (art brut, ektsentrikud, visionäärid) näitus “Omas maailmas”. Näitusega kaasnes 24.-26. maini kestnud rahvusvaheline konverents, kus ettekandeid pidasid Euroopa parimad autsaiderkunsti tundjad.

Programmis oli ettekandeid paljudelt teoreetikutelt, kunstnikelt ja terapeutidelt. Teiste hulgas kõneles loengu kunstnik Arnulf Rainer, kes kuulus Viini aktsionistide rühma. A. Raineri tegevus kunstnikuna oli tugevasti inspireeritud art brut'st, ta töötas vaimuhaiglates, teostades eksperimentaalseid projekte, ja kuulsas Gugging Haus der Künstleris.

Ürituse kohta saab lisateavet internetist (www.msl.fi/kulttuuri).

Sigrid Saarep

\section{Traditsiooniline loovus Aafrikas}

Eesti Rahva Muuseumi (ERM) näitusemajas oli 9. septembrist 2004 sama aasta lõpuni võimalik tutvuda Aafrika kunsti väljapanekuga. Näituse "Traditsiooniline loovus Aafrikas" eesmärk oli anda ülevaade Eesti Rahva Muuseumi väikesest, kuid huvitavast Aafrika kunstiesemete kogust (umbes 150 taiest). Näituse kuraator oli Laur Vallikivi, kujundaja Krista Roosi.

Kogu sai alguse 70 aastat tagasi, mil Dmitri Solomentsev kinkis muuseumile 39 taiest. Tartu Ülikooli 1925. aastal lõpetanud vennad Dmitri ja Ivan Solomentsev töötasid arstidena Belgia Kongos (praegune Kongo Demokraatlik Vabariik) ja Prantsuse Kongos (praegune Prantsuse Ekvatoriaal-Aafrika) 1920. aastate lõpul ja 1930. aastate algul. I. Solomentsev haigestus seal malaariasse ja suri 1934. aastal. D. Solomentsev, kes tõi venna surnukeha Petserisse, annetaski Aafrikast kogutud asjad 1934. aasta juunis ERMile. Teise osa Aafrikast pärit esemeid (25 taiest) kinkis D. Solomentsev ERMile 1937. aastal. Solomentsevite kogutud esemete hulgas on haruldasi näiteid rituaalsest skulptuurist ja unikaalsest 
keraamikast. Kaks aastat hiljem, 1939. aastal saadi Saksamaalt vahetusena hulk Aafrikast pärit esemeid (42 eset), valdavalt relvi ja tarbeasju.

Tänu I. ja D. Solomentsevile on ERMis suhteliselt mitmekesiselt esindatud troopilise Kesk-Aafrika - tänapäeva Kongo DV ja Kongo Vabariigi ning Gaboni - rahvaste (nt bembe, teke, kota, mangbetu) skulptuur ja keraamika. Enim leidub sellest regioonist rituaalseid puukujusid (nkisikujud), mida varem tavatseti nimetada fetišiteks. Nendel kujudel on enamasti kõhus avaus, mida täideti mulla, vere või taimedega ja mida kasutasid targad (bantu keeltes nganga) maagilisteks toiminguteks sünnitamise, matmise jt siirderiituste korral kaitseks ohtlike jõudude ja nõiduse eest. Näitusele oli välja pandud ka mujalt Aafrikast pärit asju, näiteks relvad (ennekõike vibud, nooled ja odad) ning igapäevased tarbeesemed Kamerunist, Tansaaniast ja mujalt. Kadri ja Sven Viirese fotodel on kajastatud Côte d'Ivore'is (Elevandiluurannikul) ja Ghana piirijõe Musta Volta ümbruses elava lobi hõimu saviarhitektuuri, kodualtareid ja rituaalseid puuskulptuure.

Traditsioonilist Sahhaarast lõuna pool asuva Aafrika kunsti iseloomustab eripärane esteetikataju, materjalikäsitlus ja funktsionaalsus. "Kunst kunsti pärast" on Aafrikas üsna haruldane: valdav osa esemeid, mida tavatsetakse euroopalikult kunsti alla paigutada, on loodud mingil kindlal eesmärgil. Ilu mõiste on paljudes Aafrika keeltes kattuv sõnaga 'hea', 'kohane', 'otstarbekas'. Näiteks suur osa näitusele välja pandud kujudest on loodud rituaalseks otstarbeks - need aitavad suhelda üleloomulike jõududega (kohavaimud, esivanemad) või meenutavad lihtsalt vanu müüte ja taaselustavad neid. Mittereligioossetest esemetest on paljud tehtud valitsejatele, kes kasutasid kunstiteoseid tseremooniatel oma prestiiži suurendamiseks (nt kuulsad mangbetu figuraalsed savianumad). Aafrika skulptuur on ennekõike antropomorfne, loomi kujutatakse harvem ja ka siis valdavalt inimese iseloomustamiseks. Maastikud ja taimed puuduvad Aafrika kunstist peaaegu täielikult.

Aafrika traditsiooniline kunst on vähemal või rohkemal määral köitnud eurooplasi umbes viissada aastat, muutudes vähem kui sadakond aastat tagasi eriti populaarseks Lääne-Euroopa moodsa kunsti viljelejate (fovistide, kubistide) seas. Pablo Picasso, Amedeo Modigliani, Henri Matisse, Maurice de Vlaminck, André Derain ja Juan Gris avastasid Aafrika kunsti (neegrikunst) 20. sajandi algul ning asusid oma töödes looma analoogilist vormikeelt.

Kõnealune näitus oli juba teine Aafrika kunsti ja kultuuri tutvustav näitus Eestis. Esimene korraldati aasta varem Rakvere Linnagaleriis pealkirja "Ilu ja vägi" all ja see tutvustas võrdlevalt kahe naaberrahva lobide ja baulede kunsti Belgia kunstikriitiku ja kollektsionääri Roger Pierre Turine'i kogust.

Kadri Viires 